\title{
THE EFFECTIVENESS OF APPLICATION OF GUIDED NOTE TAKING METHOD ON MATHEMATICS LEARNING OUTCOME IN STUDENTS MTS MUHAMMADIYAH KARANGKAJEN
}

\author{
Wisnu Cahya Nugraha ${ }^{a}$, Uswatun Khasanah ${ }^{b}$ \\ Program Studi Pendidikan Matematika Universitas Ahmad Dahlan \\ Jalan Ring Road Selatan, Tamanan, Banguntapan, Bantul Yogyakarta \\ awisnugraha13@gmail.com, ${ }^{\mathrm{b}}$ uswatun.khasanah@pmat.uad.ac.id
}

\begin{abstract}
The study of mathematics is still being dominated by teachers and several students who considered mathematic as an involute subject. The deficiency of variation in a particular subject may affect the student's learning result in mathematics. The objective of this research is to examine the differentiation of learning outcome of mathematic study between students applying Guided Note Taking method and Expository method as well as determining the most effective one between students using Guided Note Taking method and Expository method towards in the $8^{\text {th }}$ Grade Students of Muhammadiyah Karangkajen Islamic Junior High School, Yogyakarta. Population objected in this research are students Grade 8th ranging from the class of $8^{\text {th }} \mathrm{A}, 8^{\text {th }} \mathrm{B}, 8^{\text {th }} \mathrm{C}, 8^{\text {th }} \mathrm{D}, 8^{\text {th }} \mathrm{E}$, Even Semester, Muhammadiyah Karangkajen Islamic Junior High School (MTs), Academic Term 2015/2016, with an exact total of 161 students. The sample in this research is students from the class of $8^{\text {th }} \mathrm{A}$ as an experimental class with an exact total of 31 students and students from the class of $8^{\text {th }} \mathrm{C}$ as controlling class with a total of 33 students selected by class appointment. The data collection techniques applied in this research are normality tests conducting a formula of Chi-Quadrate, homogeneity test with a formula- $f$ and hypothesis test with a formula of -t-test. The result of a hypothesis test with a significant level $5 \%$ and latitude degree 62 pointed out that: (1) There is a difference in mathematics study which implemented the Guided Note Taking method and Expository method. This matter is explained at $t_{\text {count }}=3,4171 t_{\text {table. }}=1,9996$, therefore, $t_{\text {count }}>t_{\text {table. }}$ and (2) Study by implementing Guided Note Taking method is more effective compared to the Expository method. This matter is explained at $t_{\text {count }}=3,4171$ and $t_{\text {table. }}=1,6698$ therefore $t_{\text {count }}$ $>t_{\text {table. }}$
\end{abstract}

Keywords: Effectiveness, Guided Note Taking, Mathematics Learning Result

\section{INTRODUCTION}

The development of an increasingly modern era demands high-quality human resources, especially in the field of education. Therefore education needs to get attention from various circles, both from government, society, and families. Education is not intended to print the character and abilities of students as well as the teacher. The education process is directed at the process of functioning of all potential students humanely so that students become themselves who have superior abilities and personalities. As a process, education is interpreted as all actions that affect changes in character, personality, thinking, and behavior. Thus, education is not just a matter of examinations, the determination of graduation criteria, and the printing of diplomas. According to the Indonesian Dictionary in Shah, Muhibbin (2014: 10) education is the process of changing attitudes and behavior of a person or group of people to mature people through teaching and training. According to Tardif in Shah, Muhibbin (2014: 10) education is the whole stage of development of human abilities and behaviors, as well as the process of using almost all life experiences. Education is a very important requirement for humans. With education, humans can achieve progress in various fields which will ultimately improve one's quality. Improving the quality of education is very important to anticipate technological developments that can not be separated from the development of mathematics. Mathematics is one of the foundations in the development of science and technology. Mastery of mathematics is very necessary to survive in the future. According to Ruseffendi ET in Suherman, Erman (2003: 16) mathematics is formed as a result of human thought relating to ideas, processes, and reasoning. Mathematics is needed to meet practical needs and solve problems in everyday life. One of the benefits of learning mathematics for students is helping to understand other sciences, such as physics, chemistry, economics, etc. 
Problems in the learning process were also experienced by MTs Muhammadiyah Karangkajen, thus affecting students' mathematics learning outcomes. To find out the results of learning mathematics at the Muhammadiyah Karangkajen MTs, researchers interviewed students and a mathematics teacher at the MTs Muhammadiyah Karangkajen on November 24, 2015. Based on the results of interviews with MTs Muhammadiyah Karangkajen students, researchers found several related problems with mathematics learning. According to students, mathematics is a difficult and boring subject, some say that mathematics is an unwelcome lesson. Understanding learning Matematica according to Uno, Hamzah B. (2007: 130), the essence of learning mathematics is mental activity to understand the meaning and relationships and symbols, then applied to real situations. The results of the interviews obtained information from teachers of MTs Muhammadiyah Karangkajen that in the learning process in the classroom, the teacher used the expository learning strategy in delivering material. Even so, students are less interested in learning. Often students do not pay attention to the material explained by the teacher, often make noise in learning, lack of activeness of students in mathematics learning in the classroom, if the teacher invites the submission of questions no one asks while if given a question by the teacher, students often cannot solve it. Understanding learning outcomes according to Winkel in Purwanto (2014: 45) learning outcomes are changes that result in humans changing attitudes and behavior. According to Dimiyanti \& Mudjiono (2013: 3), learning outcomes are the results of an interaction between learning and teaching.

The above can be indicated by the results of the Middle Semester Examination of mathematics of class VIII students who are still low. The indicators of mathematics learning outcomes can be seen from the average UTS grade even semester obtained by students of class VIII A, VIII B, VIII C, VIII D, and VIII E MTs Muhammadiyah Karangkajen Academic Year 2015/2016 in Table 1 below:

Table 1. Values of middle semester exam of Even Semester Mathematics in Class VIII MTs Muhammadiyah Karangkajen

\begin{tabular}{|c|c|c|c|c|}
\hline \multirow{3}{*}{ Class } & \multirow{2}{*}{\multicolumn{2}{|c|}{$\begin{array}{c}\geq \text { MCC } 75 \\
\text { The Number Of } \\
\text { Students }\end{array}$}} & \multicolumn{2}{|c|}{$<\mathrm{MCC} 75$} \\
\hline & & & \multicolumn{2}{|c|}{ Percentage (\%) } \\
\hline & Complete & $\begin{array}{c}\text { Not } \\
\text { Completed }\end{array}$ & Complete & $\begin{array}{c}\text { Not } \\
\text { Completed }\end{array}$ \\
\hline VIII A & 0 & 31 & 0 & $100 \%$ \\
\hline VIII B & 0 & 34 & 0 & $100 \%$ \\
\hline VIII C & 0 & 33 & 0 & $100 \%$ \\
\hline VIII D & 0 & 33 & 0 & $100 \%$ \\
\hline VIII E & 0 & 30 & 0 & $100 \%$ \\
\hline
\end{tabular}

(source: MTs Muhammadiyah Karangkajen)

Based on the table above, it can be seen that the results of the mathematics learning of eighthgrade students at the MTs Muhammadiyah Karangkajen are still very low. Grade VIII students of the MTs Muhammadiyah Karangkajen have scores under the MCC (minimum completion criteria). Of the problems found at the MTs Muhammadiyah Karangkajen, the resolution must be sought. Efforts made to resolve these problems can be seen from the material or the learning method used by the teacher. Teaching material given by the teacher must be clear and the learning method used must also be appropriate.

In addition to the material given to students, it must be clear, the selection and use of appropriate learning methods are important in learning mathematics so that the use of appropriate methods is expected to affect students' mathematics learning outcomes. For that, the role of the teacher in the selection and use of learning methods must be considered. Teachers should present lessons in an interesting and can be followed by students so that students have an interest, as well as interest in participating in the process of learning mathematics. One method that can be used is the Guided Note Taking method.

From the above problems, the researchers tried to research with the title The effectiveness of Guided Note Taking learning methods on the mathematics learning outcomes of eighth-grade students of MTs Muhammadiyah Karangkajen Yogyakarta Even Semester 2015/2016 Academic Year and expected 
Guided Note Taking learning methods were more effective than learning methods which were used by math teacher MTs Muhammadiyah Karangkajen.

Based on the description of the background above, the identification of the problem is obtained as follows:

1. Some students still think mathematics as one of the difficult and boring subjects, even scary.

2. Students often do not pay attention to the teacher's explanation and often cannot answer the questions given.

3. Students often make noise in class.

4. Lack of active students in the class.

5. Student learning outcomes have not yet reached MCC

Guided Note Taking learning methods begin with providing teaching materials for example in the form of handouts from teaching materials that are delivered by the lecture method to students. Emptying some of the important points so that there are blank parts in the handout. Some ways that can be done is to empty the term or definition and eliminate some keywords. (Agus Suprijono, 2009: 124). After the explanation is complete and all students have filled in the blank points, the teacher distributes the Guided Note Taking sheet to students and is done in groups. Then one student goes forward to present the results of the group's work.

Based on the description above, the problem is formulated as follows:

1. Are there differences in the learning outcomes of mathematics using the Guided Note Taking learning method with the use of the expository method of the eighth-grade students of the Muhammadiyah Karangkajen MTs in the Yogyakarta Semester of the 2015/2016 academic year?

2. Is learning mathematics using the Guided Note Taking method more effective than using the expository method for mathematics learning outcomes in class VIII students of the MTs Muhammadiyah Karangkajen in the 2015/2016 school year?

Based on the formulation of the problem, this study aims to find out:

1. To determine whether or not there are differences in learning outcomes of mathematics by using Guided Note Taking learning methods with the use of expository methods of class VIII MTs Muhammadiyah Karangkajen in Yogyakarta City Even Semester 2015/2016 Academic Year.

2. To find out the effectiveness of learning mathematics using the Guided Note Taking method is compared with the use of the expository method on mathematics learning outcomes in class VIII MTs Muhammadiyah Karangkajen in the 2015/2016 academic year.

\section{METHODS}

In this study using a posttest-only control design. According to Sugiyono, (2011: 112). In this design, there are two groups, each chosen randomly (R). The first group is treated $(\mathrm{X})$ and the second group is not. The treated group is called the experimental group and the untreated group is called the control group. The effect of treatment is $\left(\mathrm{O}_{1}: \mathrm{O}_{2}\right)$. In real research, the effect of treatment was analyzed by different tests, using t-test statistics for example. If there is a significant difference between the experimental group and the control group, then the treatment given has a significant effect. Research Design Using Posttest-Only Control Design can be seen in table 2.

Table 2. Research Design Using Posttest-Only Control Design.

\begin{tabular}{|l|l|l|l|}
\hline Experimental Group & $\mathrm{R}$ & $\mathrm{X}_{1}$ & $\mathrm{O}_{1}$ \\
\hline Control group & $\mathrm{R}$ & $\mathrm{X}_{2}$ & $\mathrm{O}_{2}$ \\
\hline
\end{tabular}

Information :

R: Random

$\mathrm{X}_{1}$ : Experimental class that is treated using the Guided Note Taking method

$\mathrm{X}_{2}$ : The control class is a class that uses expository learning methods

$\mathrm{O}_{1}$ : The posttest results of the experimental class

$\mathrm{O}_{2}$ : The posttest results of the control class 
This research is a type of experimental research. This study was conducted at the Muhammadiyah Karangkajen MTs in Yogyakarta on the eighth-grade students of the even semester of the 2015/2016 academic year with class VIII A as the experimental class and class VIII C as the control class. A variable that was used in this study was the application of Guided Note Taking learning methods and the results of mathematics learning in class VIII of MTs Muhammadiyah Karangkajen in Yogyakarta. Data collection techniques in the form of documentation methods and test methods. The data collection instrument is a test of mathematics learning outcomes. Data analysts use the normality test, homogeneity test, and t-test.

Normality Test uses Chi-Squared formula $X^{2}$ :

$$
\chi^{2}=\sum_{i=1}^{k} \frac{\left(O_{i}-E_{i}\right)^{2}}{E_{i}}
$$

Information :

$x^{2} \quad$ : Chi-square value

$O_{i} \quad$ : Frequency of observation in the class interval to i

$E_{i} \quad$ : Expected frequency on interval class $-\mathrm{i}$

$k \quad:$ The number of interval classes

$i \quad: 1,2, \ldots \mathrm{k}$

$X^{2}$ obtained from the results of the calculation then combined with the value $X^{2}$ table with degrees of freedom $(\mathrm{df})=\mathrm{k}-1$ at a significance level of $5 \%$.

Test criteria:

If $X^{2}$ count $\leq X^{2}$ table, then accept $\mathrm{H}_{0}$ (the population is normally distributed).

If $X_{\text {count }}^{2}>\mathcal{X}^{2}$ table , then reject $\mathrm{H}_{0}$ (the population is not normally distributed).

( Suparman, 2012: 6 )

Homogeneity test uses the F statistical test formula, namely:

where the variance of each sample is:

$$
F_{0}=\frac{S_{1}^{2}}{S_{2}{ }^{2}}
$$

$$
S_{i}^{2}=\frac{1}{n-1} \sum_{i=1}^{n}\left(x_{i}-\bar{x}\right)
$$

Information :

$n \quad=$ Number of data

$S_{i}^{2} \quad=$ Sample variant to $-\mathrm{i}$

$k \quad=$ Many treatments

Test criteria:

Refuse $\mathrm{H}_{0}$ if $\mathrm{F}_{0}>F_{\alpha / 2}\left(n_{1}-n_{2}\right)$.

( Suparman, 2011:48 )

The test formula is that:

$$
t=\frac{\bar{X}_{1}-\bar{X}_{2}}{S_{p} \sqrt{\frac{1}{n_{1}}+\frac{1}{n_{2}}}}
$$

Where :

$$
S_{p}^{2}=\frac{\left(n_{1}-1\right) S_{1}^{2}+\left(n_{2}-1\right) S_{2}^{2}}{\left(n_{1+} n_{2}\right)-2}
$$

(Suparman, $2011: 46$ ) 
Information :

$\mathrm{t} \quad$ : Price $\mathrm{t}$

$\bar{X}_{1} \quad$ : Student scores with the Guided Note Taking learning method

$\bar{X}_{2} \quad$ : Values students with expository learning

$n_{1} \quad$ : The number of students using the Guide Note Taking learning method

$n_{2} \quad$ : Number of Expository learning students

$S_{1}{ }^{2} \quad$ : Student variants of the Guide Note Taking learning method

$S_{2}{ }^{2} \quad$ : Student expository learning variance (control class)

$S_{p} \quad$ : Combined standard deviation

\section{RESULTS AND DISCUSSION}

Before being given the treatment of the experimental class and the control class, an initial ability test was conducted on the population. The normality test is used to determine whether the value of the initial mathematical ability of the experimental class students and the control class is normally distributed or not. The summary of the results of the normality test of the initial mathematical ability of students in the experimental class and the control class can be seen in Table 3 .

Table 3. Summary of Initial Ability Normality Test Results

\begin{tabular}{|l|l|c|l|l|}
\hline Class & $\boldsymbol{\chi}_{\text {count }}^{\mathbf{2}}$ & $\mathbf{d f}$ & $\boldsymbol{\alpha}$ & $\boldsymbol{\chi}_{\text {table }}^{\mathbf{2}}$ \\
\hline $\mathrm{A}$ & 2,7372 & 2 & $5 \%$ & 5,9915 \\
\hline $\mathrm{C}$ & 3,9336 & 3 & $5 \%$ & 5,9915 \\
\hline \multicolumn{4}{|l}{ Information } & \multicolumn{2}{|l}{ Normal distribution } \\
\hline
\end{tabular}

Based on the conclusions in the table above, it appears that in the experimental class $\chi_{\text {cont }}^{2}=2,7372$ and $\chi_{\text {table }}^{2}=5,9915$ so $\chi_{\text {count }}^{2}<\chi_{\text {table }}^{2}$ at a significant level of 5\% and degrees of freedom 2 and in the control class $\chi_{\text {count }}^{2}=3,9336$ and $\chi_{\text {table }}^{2}=7,8147$ so $\chi_{\text {count }}^{2}<\chi_{\text {table }}^{2}$ at a significant level of $5 \%$ and degrees of freedom 3 . It can be concluded that the value of the initial ability of mathematics comes from data that are normally distributed.

To find out that the population of class VIII MTs Muhammadiyah Karangkajen Yogyakarta has the same or homogeneous variance. The results of the homogeneity test of the early abilities of the VIII students of MTs Muhammadiyah Karangkajen Yogyakarta can be seen in Table 4 below:

Table 4. Homogeneity Test Results of the Early Ability of Class VII Students

\begin{tabular}{|l|l|l|c|}
\hline df & $\alpha$ & $f_{0}$ & $f_{\text {table }}$ \\
\hline$(30,32)$ & $5 \%$ & 0,5947 & 2,0408 \\
\hline information & \multicolumn{3}{|l|}{ Homogeneous } \\
\hline
\end{tabular}

Based on the homogeneity test that has been done in class VIII A and VIII C it can be seen that $F_{0}=0,5947$ and $f_{0,025}(30,32)=2,0408$, so $F_{0}<f_{\text {table }}$ which means that both classes have the same variance (having a homogeneous variance).

After it was discovered that the grade VIII students were homogeneous, then the instrument was tested in the trial class. Data analysis from this research instrument shows that out of 25 questions, 9 questions are invalid. So that the number of questions used to test the mathematics learning outcomes of class VII students is 15 questions based on advice from Mr. Suwarso to facilitate the calculation of school data. While from the 15 items, it is known to have a very high-reliability level. The questions that are valid reliable and have good differential power are then given to the experimental class, namely the class that uses the Guided Note Taking learning method and the control class that uses the Expository method. The results of the mathematics learning outcomes test can be seen in solid Table 5 below: 
Table 5. Description of the result of Mathematics Learning Outcomes

\begin{tabular}{|c|c|c|c|c|c|}
\hline \multirow{2}{*}{ Class } & \multicolumn{5}{|c|}{ Parameter } \\
\cline { 2 - 6 } & $\begin{array}{c}\text { Max } \\
\text { Value }\end{array}$ & $\begin{array}{c}\text { Min } \\
\text { Value }\end{array}$ & $\bar{X}$ & $\boldsymbol{S}$ & $\mathbf{S}^{\mathbf{2}}$ \\
\hline $\mathrm{A}$ & 100 & 66,67 & 79,3552 & 8,3194 & 69,2118 \\
\hline $\mathrm{C}$ & 93,33 & 40 & 70,1009 & 12,8154 & 164,2354 \\
\hline
\end{tabular}

Table 5 shows the minimum value, maximum value, and the average value of the experimental and control classes. It can be seen that the average value of the experimental class is higher than the mean value of the control class. Then the two-party hypothesis was tested to determine whether there were differences in mathematics learning outcomes between the experimental class and the control class. The results of the two-party hypothesis test can be seen in Table 6 below:

Table 6. Summary of the First Hypothesis Test for Mathematics Learning Outcomes

\begin{tabular}{|c|c|c|c|}
\hline $\mathbf{d f}$ & $\boldsymbol{\alpha}$ & $\boldsymbol{t}_{\text {count }}$ & $\boldsymbol{t}_{\text {table }}$ \\
\hline 62 & $5 \%$ & 3,4171 & 1,9996 \\
\hline \multicolumn{2}{|c|}{ Information } & \multicolumn{2}{|c|}{$\mathrm{H}_{0}$ rejected } \\
\hline
\end{tabular}

Based on the results of the analysis carried out with a significant level of $5 \%$ and 62 degrees of freedom, the values obtained $t_{\text {count }}=3,4171$ and $t_{\text {table }}=1,9996$, so $t_{\text {count }}>t_{\text {table }}$ Then reject it $\mathrm{H}_{0}$ and $\mathrm{H}_{1}$ accepted which means that there are differences in mathematics learning outcomes using Guided Note Taking learning methods with expository learning methods in class VIII even semester of MTs Muhammadiyah Karangkajen in Yogyakarta academic year 2015/2016.

Furthermore, one-party hypothesis testing is done to find out whether learning using Guided Note Taking learning methods is more effective than expository learning methods. The results of the second hypothesis test can be seen in Table 7 below.

Table 7. Second Hypothesis Test for Mathematics Learning Outcomes

\begin{tabular}{|c|c|c|c|}
\hline $\mathbf{d f}$ & $\boldsymbol{\alpha}$ & $\boldsymbol{t}_{\text {count }}$ & $\boldsymbol{t}_{\text {table }}$ \\
\hline 62 & $5 \%$ & 3,4171 & 1,6694 \\
\hline \multicolumn{3}{|c|}{ Information } & \multicolumn{2}{|c|}{$\mathrm{H}_{0}$ rejected } \\
\hline
\end{tabular}

Based on the results of the analysis carried out with a significant level of 5\% and 62 degrees of freedom, the values obtained $t_{\text {count }}=3,4171$ and $t_{\text {table }}=1,6694$, so $t_{\text {count }}>t_{\text {table }}$ Then reject it $\mathrm{H}_{0}$ and $\mathrm{H}_{1}$ accepted which means that learning using the Guided Note Taking learning method is more effective than the expository learning method in class VIII in the even semester of MTs Muhammadiyah Karangkajen in the academic year 2015/2016.

\section{CONCLUSION}

Based on the results of the research and discussion as described, the research conclusions can be taken as follows:

1. There are differences in mathematics learning outcomes using Guided Note Taking learning methods with expository learning methods in class VIII MTs Muhammadiyah Karangkajen in Yogyakarta City Even Semester 2015/2016 Academic Year. This is indicated by the results of the first hypothesis test wherewith a significant level of $5 \%$ and the degree of freedom $=62$, a value is obtained $t_{\text {count }}=$ 3,4171 and $t_{\text {table }}=1,9996$, so $t_{\text {count }}>t_{\text {table }}$ Then reject it $\mathrm{H}_{0}$ and $\mathrm{H}_{1}$ accepted Then reject it $\mathrm{H}_{0}$ and $\mathrm{H}_{1}$ accepted.

2. Learning mathematics using Guided Note Taking learning methods is more effective than expository learning methods in class VIII MTs Muhammadiyah Karangkajen Yogyakarta even semester $2015 / 2016$. This is indicated by the results of the second hypothesis test where a significant level of 
$5 \%$ and 62 degrees of freedom are obtained $t_{\text {count }}=3,4171$ and $t_{\text {table }}=1,6694$, so $t_{\text {count }}>$ $t_{\text {table }}$ Then reject it $\mathrm{H}_{0}$ and $\mathrm{H}_{1}$ accepted.

\section{REFERENCES}

Agus Suprijono. 2009. Cooperative Learning. Teori Aplikasi PAIKEM. Yogyakarta: Pustaka Belajar Erman Suhernan, dkk. 2003. Strategi Pembelajaran Matematika Kontemporer. Bandung: Jica

Muh. Yusuf Mappease. 2009. Pengaruh Cara Dan Motivasi Terhadap Hasil Belajar Programmable Logic Controller (PLC) Siswa Kelas III Jurusan Listrik SMK Negri 5 Makasar. Jurnal MEDTEK: Volume 1 Nomor 2

Muhibbin Syah. 2014. Psikologi Pendidikan. Bandung: PT REMAJA ROSDAKARYA

Purwanto. 2014. Evaluasi Hasil Belajar. Yogyakarta: Pustaka Belajar

Sugiyono. 2013. Metode penelitian pendidikan ( pendekatan kuantitif, kualitatif dan $R \& D$ ). Bandung: Alfabeta

Suparman. 2011. Metodologi Penelitian Pendidikan. Yogyakarta: MIPA Universitas Ahmad Dahlan Press

2012. Desain dan Analisis Eksperimen. Yogyakarta : Universitas Ahmad Dahlan 